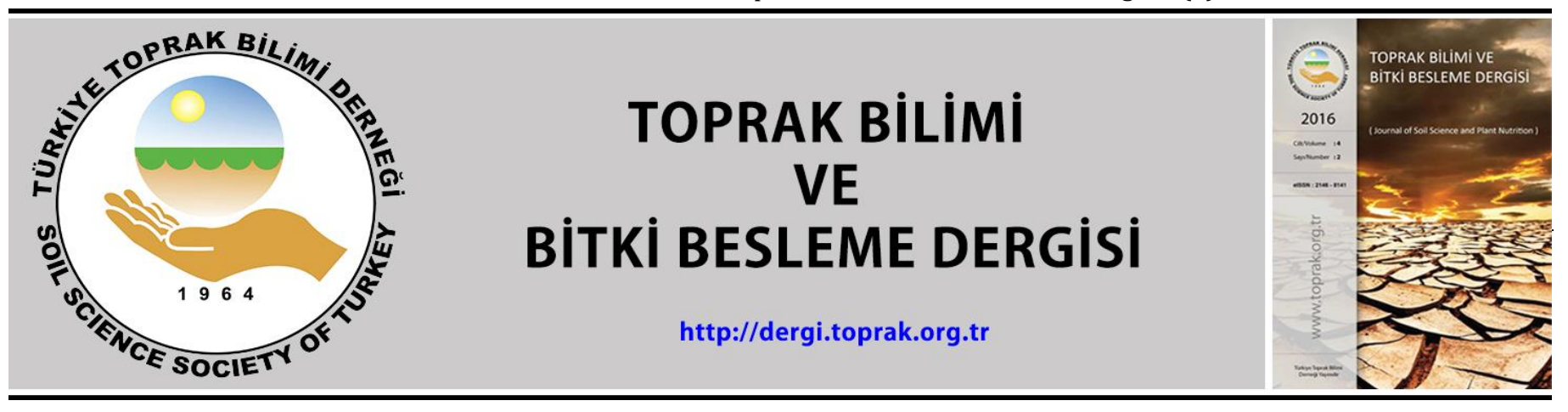

\title{
Sakarya ili ormanlık alan topraklarından Streptomyces türlerinin izolasyonu, karakterizasyonu ve bazı ekstraselüler enzimlerin üretiminin belirlenmesi
}

\author{
Ömrüye Özok ${ }^{1, *}$, Kerem Özdemir ${ }^{2}$ \\ 1 Van Yüzüncü Yıl Üniversitesi, Fen Fakültesi, Moleküler Biyoloji ve Genetik Bölümü, Van \\ 2 Bandırma 17 Eylül Üniversitesi, Mühendislik ve Doğa Bilimleri Fakültesi, Mühendislik Temel Bilimleri Anabilim Dalı, \\ Ballkesir
}

\begin{abstract}
Özet
Bu çalışmada, Sakarya ili sınırlarında bulunan ormanlık alan topraklarından Streptomyces cinsi bakterileri izole edilerek bilgisayar yardımıyla teşhisleri yapılmış ve izolatların amilaz, selülaz, L-asparaginaz, proteaz ve lipaz enzimlerinin aktiviteleri belirlenmiştir. Yapılan renk grubu analizinde izolatlar havasal ve misel rengi esas alınarak 4 ana gruba ayrılmıştır. Teşhisleri tamamlanan Streptomyces izolatlarının test sonuçları MVSP 3.2 bilgisayar programı ile birbirleri arasındaki benzerlik dendogramları oluşturulmuştur. Tüm izolatların fenotipik ve biyokimyasal karakterleri belirlenerek IDENTAX bilgisayar programına bu veriler aktarılmış, cins içerisindeki pozisyonları belirlenerek teşhisleri yapılmıştır. Bu teşhislere göre 80 izolattan 49'unun Streptomyces exfoliatus, 14'ünün Streptomyces atroolivaceus, 1'i Streptomyces albidoflavus,1'i Streptomyces chromofuscus, 1'i de Streptomyces purpureus olduğu belirlenmiştir. Ayrıca tüm izolatların proteaz, amilaz, lipaz, selülaz ve asparaginaz enzim aktiviteleri belirlenmiștir.
\end{abstract}

Anahtar Kelimeler: Streptomyces, ekstraselüler enzim, karakterizasyon.

\section{Isolation and identification of Streptomyces species isolated from forest area (Sakarya City) and determination the production of some extracellular enzyme}

\begin{abstract}
In this study, forest area located in the province of Sakarya city soil bacteria of the genus Streptomyces isolated and made computerassisted diagnosis and various enzyme activities of the isolates were determined. All isolates of phenotypic and biochemical characteristics of the data being transmitted to the computer program determined IDENTAX, diagnosis is made by determining their position in the genus. Isolates in the color group analysis based on aerial and substrate mycelium color is divided into four main groups. Diagnostic test results of Streptomyces isolates are completed by a computer program MVSP 3.2and were created similarity dendograms. In addition, all isolates protease, amylase, lipase, cellulase and asparaginase enzyme activity was determined.
\end{abstract}

Keywords: Streptomyces, Extracellular enzyme, characterization.

(C) 2019 Türkiye Toprak Bilimi Derneği. Her Hakkı Saklıdır

\section{Giriş}

Genel olarak habitatları toprak olan Streptomyces bakterileri selüloz, lignin, kitin gibi doğal polimerlerin degredasyonunda ve döngüsünde rol alan mikrobiyal topluluğun önemli bir bileșeni olmalarının yanısıra (Semêdo ve ark., 2004), yapısal olarak farklı ve biyolojik olarak aktif çok sayıda bileşiğin kaynağı olarak biyoteknolojik açıdan da önemli bir potansiyele sahiptir (Semêdo ve ark., 2004). Actinomycetales takımının bu üyeleri, antibiyotiklerin ve endüstriyel yönden yararlı enzim, enzim inhibitörü gibi sekonder metabolitlerin kaynağı olarak bilinmekle birlikte, şimdiye kadar keşfedilmiş, doğal olarak meydana gelen antibiyotiklerin yarısından fazlasının bu organizmalar tarafından üretildiği bildirilmiştir (Hayakawa ve ark.,

\footnotetext{
* Sorumlu yazar:

Tel. : : $\quad 05448982540$

E-posta : o.ozok@hotmail.com
}

Geliş Tarihi : $\quad 30$ Aralık 2018

Kabul Tarihi ： 21 Nisan 2019 $\begin{array}{rll}\text { e-ISSN } & : & 2146-8141 \\ \text { DOI } & : & 10.33409 / \text { tbbbd.595174 }\end{array}$ 
2004). . Streptomyces cinsi üyelerinin yeni, ticari olarak önemli ve farmokolojik olarak aktif anitibiyotik, enzim, enzim inhibitörü gibi antimikrobiyal madde üretme yetenekleri Streptomyces bakterilerini prokaryotlar arasında önemini artırmaktadır. Endüstrinin hemen her alanında kullanılan enzimler genellikle mikroorganizmalardan elde edilmektedir. Bunun nedeni mikroorganizma kaynaklı enzimlerin bitkisel veya hayvansal kaynaklı enzimlere göre katalitik aktivitelerinin çok yüksek olmaları, istenmeyen yan ürün oluşturmamaları, daha stabil ve ucuz olmaları, fazla miktarda elde edilebilmeleridir (Wiseman, 1987). Bu mikroorganizmalar yalnızca enzim üretme yeteneklerine göre değil, mikroorganizmaların toksik ve patojen olmamasına göre de seçilmiştir. Bugün endüstride kullanılan birçok enzim mikrobiyal kökenli olduğu için, endüstriyel enzimlerin kullanımında, mikroorganizma kullanımı artmıștır (Demain ve Solomon, 1981). Antimikrobiyal maddeler, çok az yoğunlukta dahi mikroorganizma gelişimini engelleyen biyolojik kökenli sekonder metabolitler olup, mikroorganizmanın çoğalmasını engelleyici "bakteriostatik" veya "fungustatik" olabildikleri gibi; mikroorganizmanın ölümüne sebep olan "bakterisidal" veya "fungusidal" maddelerde olabilirler. Mikroorganizmalar tarafından üretilen, düşük molekül ağırlıklı, organik doğal ürünler olan antimikrobiyal maddeler seçici toksititeye sahip olduklarından çok düşük konsantrasyonlarda bile mikroorganizmaya zararlı olup makroorganizmaya zarar vermezler.

Bu çalışmada amaç; Sakarya ili ormanlık alanlarından toplanan toprak numuneleri kullanılarak izole edilen Streptomyces bakterilerinin karakterizasyon ve bilgisayar destekli teşhisi yapılarak, izole edilen tüm bakterilerin çeşitli enzim aktiviteleri de (amilaz, proteaz, lipaz, selülaz, asparaginaz) belirlenmeye çalışılmıştır.

\section{Materyal ve Yöntem}

Bu araştırmanın materyalini Sakarya ilinin 5 farklı lokasyonlarından özellikle ormanlık alanlardan alınan toprak numuneleri oluşturmaktadır. 1. lokasyon Karaçam çıkışı, 2. lokasyon Doğançay/aşağı mahalle, 3.lokasyon Doğançay/Yukarı mahalle, 4. lokasyon Geyve/kuzey, 5. lokasyon Geyve/güney olarak belirlenerek alınan toprak numunelerinin laboratuarda nem ve $\mathrm{pH}$ değerleri belirlenmiştir.

\section{Streptomyces Türlerinin İzolasyonu ve Saflaştırılması}

Bu çalışmada Streptomyces bakterilerinin izolasyonu için klasik dilüsyon ve yüzeye yayma yöntemi kullanıldı. Daha sonra, her toprak örneğinden 1 gr tartılarak içerisinde $9 \mathrm{ml}$ ringer çözeltisi bulunan 20 ml'lik steril cam şişelere konuldu. Her bir toprak örneği homojen hale getirildi ve otomatik pipet ile aseptik şartlarda $0.5 \mathrm{ml}$ alınarak içerisinde $4.5 \mathrm{ml}$ ringer çözeltisi bulunan steril cam tüplere konuldu. Streptomyces bakterilerinin izolasyonu için M65 besi yeri hazırlandı ve $25^{\circ} \mathrm{C}^{\prime}$ de 14 gün inkübasyona bırakılan izolasyon plaklarındaki olası farklı Streptomyces suşları, koloni morfolojileri dikkate alınarak seçilmiştir. İzole edilen bu koloniler cycloheximide $(50 \mathrm{ug} / \mathrm{ml})$, nystatin $(50 \mathrm{ug} / \mathrm{ml})$ ve novobiosin $(0.5 \mathrm{ug} / \mathrm{ml})$ ilaveli Bennet's Agar besiyeri (DSMZ) yüzeyine çizgi plak yöntemiyle transfer edilerek tek koloni düşürülmeye çalışıldı. Bu işlem, saf kültürler elde edilene kadar tekrarlanmıştır.

\section{Renk Gruplandırması}

Saflaştırılan toplam 80 Streptomyces suşunun renk gruplandırılması için Oatmeal Agar (Shirling ve Gottlieb, 1966) besi ortamına ekimi yapıldı. Çizgi ekim metoduyla inoküle edilen izolatlar 14 gün $28^{\circ} C^{\prime}$ de inkübe edildikten sonra havasal miselyum rengi substrat miselyum renkleri renk kataloğuna göre tespit edildi ve gruplandırma yapıldı. İzolatların melanin pigmenti üretip üretmediğini belirlemek için pepton yeast extract iron agar (Shirling ve Gottlieb, 1966) besi ortamına öze yardımıyla ekim yapıldı ve $28^{\circ} \mathrm{C}$ 'de 7 gün süre ile inkübasyona bırakıldı. İnkübasyon sonunda petri kabı içerisinde üremiş olan kolonilerden siyahımsı renk oluşumu melanin pigmenti üretiminin olduğunu, renk değişimi olmamış koloniler ise melanin üretmeyen koloniler olarak değerlendirilmiştir. Sonuçta hem havasal ve substrat miselyum renk hem de melanin pigment üretimi dikkate alınarak tüm izolatlar gruplandırıldı.

\section{Antimikrobiyal Aktivite Çalışmaları}

Daha önceden saflaştırılıp $-20^{\circ} \mathrm{C}$ 'de gliserol içerisinde saklanan Streptomyces izolatları 6 adet patojen yada non-patojen (S.pneumonia,E.fealeus, E.coli,S.aureus, S.flexneri, P.aerogmose) test organizmasına karşı antimikrobiyal aktiviteleri incelenmiştir (Williams ve ark., 1983a). Bennet's agar besi yerine ekilen Streptomyces test izolatları $27^{\circ} \mathrm{C}$ 'de 3 gün süre ile aktive edildikten sonra kullanılmış, hazırlanan besiyerinin merkezine çizgi şeklinde her izolat ayrı olarak ekilmiştir. Plak kapları 2 gün süre ve $27^{\circ} \mathrm{C}$ 'de inkübasyona bırakıldı. İnkübasyon süresi sonunda üremiş olan Streptomyces bakterilerine dik çizgi yöntemi ile patojen test organizmalarının ekimi yapılarak $37^{\circ} \mathrm{C}$ 'de tekrar inkübasyona bırakılmıştır. Sonuçlar test organizmalarının etrafındaki şeffaf zona bakılarak duyarlıyada dirençli olarak kaydedilmiştir. 


\section{Antibiyotik Duyarlılık Testleri}

Bakterilerin antibiyotiklere karşı duyarlılıklarının belirlenmesi için yapılan çalışmada hazırlanan besi ortamına sıvı solüsyon olarak hazırlanmış Streptomyces bakterileri yayma metodu ile ekim yapılmış ve ticari antibiyotikler (neomisin, oleondamisin, penisilin G, rifamisin) laboratuar ortamında disklere emdirme metoduyla hazırlanan antibiyotik diskler șeklinde petri kaplarına yerleștirilmiștir. 2-3 gün $27^{\circ} \mathrm{C}$ 'de inkübasyondan sonra disklerin etrafında meydana gelen şeffaf inhibisyon zonlarına göre o bakterinin diskte bulunan antibiyotiğe duyarlı olduğu belirtilmiştir.

\section{Degredasyon Aktiviteleri}

İzolatlar Ksantin \%0.4, Tween $80 \% 1$, Elastin \%0.3, Guanin \%0.05, Arbutin \%1, Tirozin \%0,05, Kazein \%1, Üre \%1, Jelatin \%1, Nișasta \%1, Tallus acetat olmak üzere 11 substratı degrede edebilme özelliklerine göre incelenmiștir. Streptomyces suşları her bir madde için ayrı ayrı besi yerine standart olarak $7 \mu$ l ekim yapılmıș, degredasyon testleri için Bennett’s Agar (Jones, 1949) kullanılmıștır.

\section{Enzim Aktivitelerinin Belirlenmesi}

\section{Amilaz}

Amilaz enzimi üretimi için Bennet's agar hazırlanarak \%2'lik nişasta ilave edilmiş ve $28^{\circ} \mathrm{C}$ 'de 4 gün inkübe edilmiştir. Besi yeri üzerine lügol damlatılarak etrafında açık renk zon oluşturan bölgeler pozitif sonuç olarak seçilmiştir (Aygan ve ark. 2008).

\section{Selülaz}

Selülaz enzimi üretimi için Bennet's agar hazırlanarak \%1 'lik karboksi metil selülaz (saf suda çözülerek) ilave edilmiş ve $28^{\circ} \mathrm{C}$ 'de 4 gün inkübe edilmiștir. Besi yeri üzerine $\% 1$ 'lik Kongo red ilave edilerek koloni etrafında açık sarı renk zon oluşumu pozitif sonuç olarak seçilmiştir. (Hakamada ve ark., 1997).

\section{L-Asparaginaz}

Asparaginaz enzimi üretimi için Bennet's agar hazırlanarak \%1'lik asparagin ilave edilmiş ve $28^{\circ} \mathrm{C}^{\prime}$ de 4 gün inkübe edilmiştir. Besi yeri üzerine 3 damla fenol damlatılarak etrafında pembeye dönüșen koloniler pozitif sonuç olarak seçilmiştir (Gulati ve ark., 1997).

\section{Proteaz}

Proteaz enzimi üretimi için Bennet's agar hazırlanarak \%1'lik yağsız süt tozu ilave edilmiş ve $28^{\circ} \mathrm{C}^{\prime}$ de 4 gün inkübe edilmiştir. Besi yeri üzerinde etrafında açık renk zon oluşturan bölgeler pozitif sonuç olarak seçilmiştir (Yin ve ark., 2010).

\section{Lipaz}

Lipaz enzimi üretimi için Bennet's agar hazırlanarak \%2'lik Tween 80 ilave edilmiş ve $28^{\circ} \mathrm{C}^{\prime}$ de 4 gün inkübe edilmiştir. Besi yeri üzerine \%0,001'lik rodamin b ilave edilereketrafında açık renk zon oluşturan koloniler pozitif sonuç olarak seçilmiştir (Karnetova ve ark.,1984).

\section{Bulgular ve Tartışma}

Beş farklı lokasyondan alınan toprak numunelerinin izolasyon öncesinde $\mathrm{pH}$ ve nem oranları Çizelge 1'de gösterilmiştir. Numunelerin pH 'ları 6,13 (1 nolu numune, Karaçam çıkışı) ile 7,16 (4 nolu numune, Geyvekuzey) arasında değişti ve bu sonuçlarla nötral toprak tipini oluşturdukları belirlendi. Nem oranları ise \%4 (1 nolu numune, Karaçam çıkışı ) ile \%9 (3 nolu numune, Doğançay-yukarı mahalle ) arasında değişiklik gösterdi. Bu sonuçlarımız daha önce Streptomyces türleri üzerine yapılan biyoçeşitlilik çalışmalarıyla uygunluk göstermiștir (Vickers ve ark., 1984; Williams ve Vickers, 1988; Özdemir, 2008). Streptomyces bakterilerinin izolasyonu konusunda bugüne kadar yapılan çalışmalarda genellikle bitki yetişme alanlarına yakın bölgelerden toprak numuneleri alınmıștır (Özdemir, 2008).

$\mathrm{Bu}$ çalışmada toplam 5 toprak numunesinden Streptomyces bakterilerinin izolasyonu yapıldı. Cycloheximid $(50 \mathrm{ug} / \mathrm{ml})$, Nystatin $(50 \mathrm{ug} / \mathrm{ml})$, Novabiosin $(50 \mathrm{ug} / \mathrm{ml})$ antibiyotikleri eklenmiş M65 besiyerinde gelişen Streptomyces kolonileri diğerlerinden oluşturdukları karakteristik misel ve pigment durumlarına göre seçilerek izolasyonları gerçekleștirilmiştir. Ayrıca yapılan tüm izolasyon çalışmaları sonucunda sayılan Streptomyces bakterilerinin ve toplam canlı bakterilerin sayım sonuçları Şekil 1'de verilmiştir. 


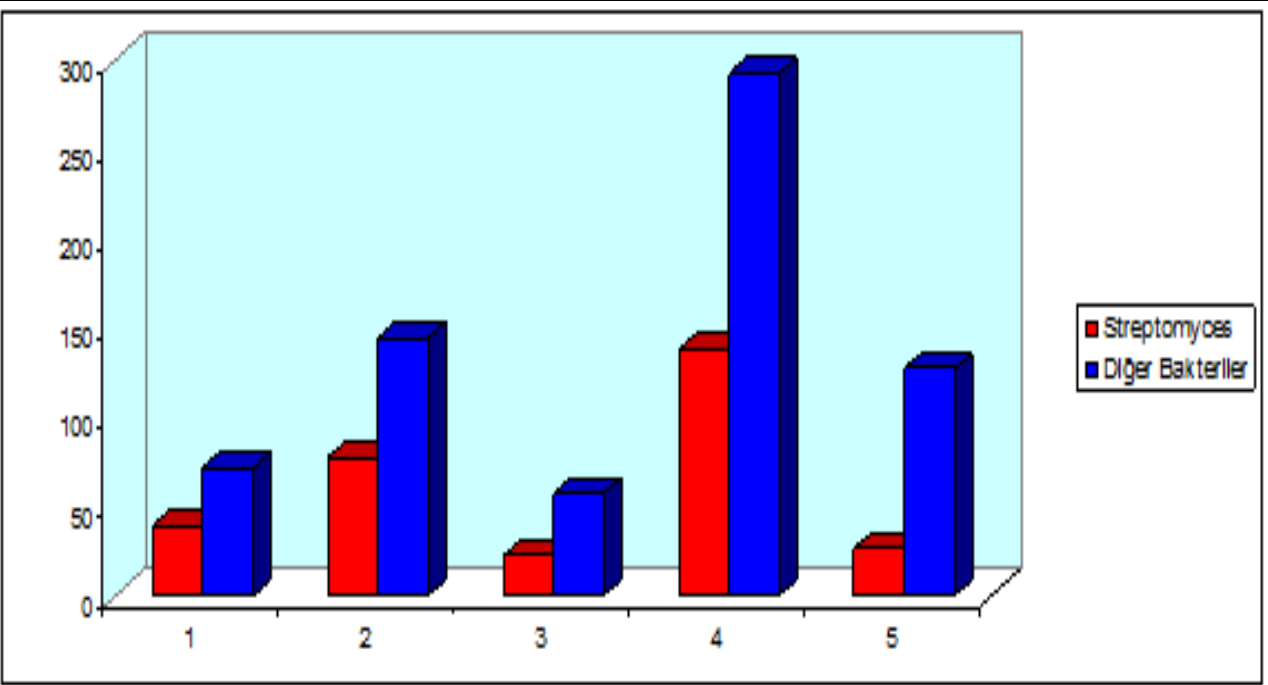

Şekil 1. İzolasyon çalışması sonucu Streptomyces için Medium 65 agar besi ortamındaki izolatların toplam bakteri sayım sonuçları.
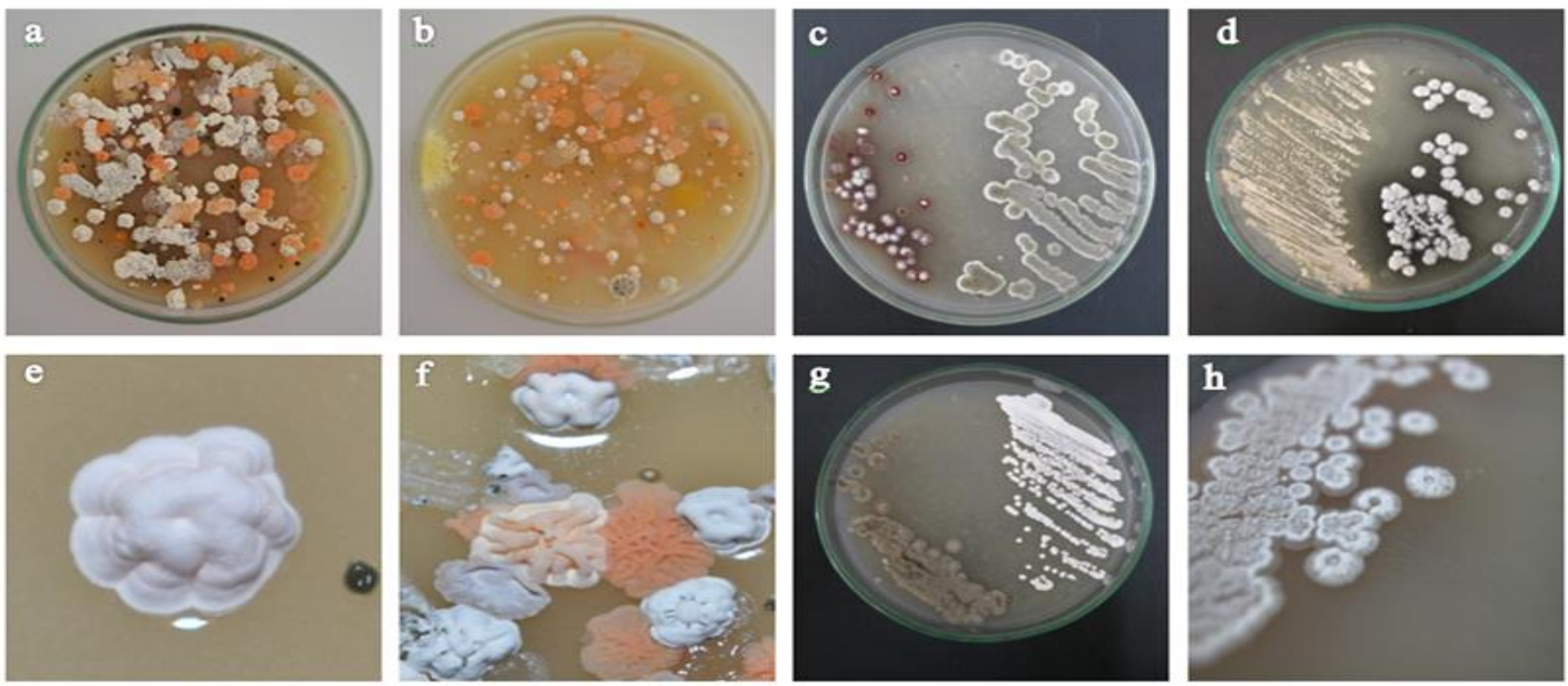

Şekil 2.İzolasyonu yapılan ve saflaştırılan Streptomyces kolonileri. a, b: izolasyon petrileri, c, d, g, h: saflaştırma petrileri, e, f: koloni morfolojileri.

\section{Renk Gruplandırması}

Saflaştırılan toplan 80 Streptomyces izolatı Oatmeal Agar besi ortamında ekim sonucu Streptomyces test izolatları havasal miselyum rengine göre 4 ana renk grubuna ayrılmıştır.1.grup havasal miselyum rengi beyaz, 2.grup havasal miselyum rengi sarl, 3. Grup havasal miselyum rengi yeşil ve 4.grup havasal miselyum rengi gri olarak belirlenmiştir.4 ana renk grubuna ayrıldıktan sonra substrat ve melanin üretimi dikkate alınarak yapılmış ve izolatlar 22 (Beyaz), 37 (Sarı),15 (Gri), ve 3 (Pembe) test organizması içermiştir. Oluşan bu gruplar daha önce yapılan izolasyon ve teşhis çalışmaları ile uygunluk göstermektedir (Atalan ve ark., 2000). Renk grubuna göre ayrılan 4 ana grubun üyelerinin çoğunlukla aynı izolatlar olduğunu belirlenirken, özellikle havasal misel rengi gri olan izolatların IDENTAX teşhis programına göre de Streptomyces exfoliatus olarak kesin teşhisi yapılabilmiş, renk grubu ile teşhis matriksi arasında uygunluk gösterdiği belirlenmiştir.

\section{Antimikrobiyal Aktivite}

Saflaştırılmış olan 80 Streptomyces suşu toplamda 4 adet patojen ve nonpatojen test mikroorganizmasına karşı antimikrobiyal aktivite özelliklerinin belirlenmesi amacıyla Bennet's agar içeren besi ortamına ekildi. Ekimi yapılan suşların bulunduğu petri kapları 24 saat boyunca $37{ }^{\circ} C^{\prime}$ de inkübasyona bırakıldıktan sonra türlerin test engel organizmalarına karşı antimikrobiyal aktiviteleri belirlendi. Çalışmada kullanılan Escherichia colitye Streptomyces izolatlarının \% 16,25'i antagonistik etki gösterdi. Diğer patojen ve nonpatojen test mikroorganizmalarından Salmonella pneumonia ve Enterococcus faecalis \% 8,25'i, Staphylococcus aureus \% 87,5'i, Shigella flexneri \% 31,25'i, Pseudomonas aeruginosa \% 13,75'i antimikrobiyal 
aktivite göstermiştir. Birçok yazar ayrıca Streptomyces izolatlarının gram-pozitif bakterilere karşı oldukça aktif göründügünü bildirmiștir (Hamdi ve ark., 1980; Hussein ve ark., 1980; Saadoun ve ark., 1998). Yapmıș olduğumuz çalışmada özellikle Staphylococcus aureus'a gösterilen mikrobiyal aktivite ile daha önceki çalışmalarla paralellik göstermiş̧tir. Seçkin (2018) yaptığı çalışmada gözlemler sonucunda Streptomyces izolatlarının \% 28.49'u Esherichia coli'ye, \% 48.04'i Staphylococcus aureus'a ve \% 6.70'i Pseudomonas aeruginosa'ya karşı antagonistik etkide bulunduğunu belirtmiştir.

\section{Antibiyotik Duyarlılık Testleri}

Test organizmalarının Neomisin $(100 \mu \mathrm{g} / \mathrm{ml})$, Rifampisin $(50 \mu \mathrm{g} / \mathrm{ml})$, Oleoandomisin $(100 \mu \mathrm{g} / \mathrm{ml})$ ve Penisilin G (50 $\mu \mathrm{g} / \mathrm{ml})$ antibiyotiklerine karşı duyarlılıkları tespit edildi. Tüm izolatların \%83,75'i Neomisine, \%71,25'i Rifamisine, \%63,75'i Penisilin G , \%17,50'i Oleandamisine dirençli olduğu belirlendi. Orhan (2013)'nın yapmış olduğu çalışmada izolatların tümünün Oleandamisin ve Penisilin G'ye direnç gösterdiğini ortaya koymuştur. Seçkin (2018)'in çalışmasında 177 izolat içerisinde izolatların neredeyse \%50'sinin Penisilin G ve Oleandamisin'e direnç gösterdiğini belirtmiştir. Yapılan çalışmaların sonuçlarının farklı olması muhtemelen farklı habitatlardan kaynaklanmaktadır.

\section{Degredasyon Aktiviteleri}

Streptomyces suşlarının \%96,75'i ksantini, \%99,6 elastini, \%100'ü guanin, tirozin, nişasta ve tween 80'i, \%99,8'i arbutini, \%77,25'i üreyi, \%95'i jelatini, \%97,5'i kazeini, degrede edebilme kabiliyeti gözlenirken, tallus asetat hiçbir izolatta degrede yeteneği göstermemiştir. Orhan (2013) ve Seçkin (2018) yapmış olduğu degredasyon testlerinde sonuçlar \%80 üzerindedir ve bu çalışmamızla paralellik göstermiştir. Ertaş ve ark., (2013)'nın yapmış olduğu çalışmada da yine Actinomycetales ordosuna ait Micromonosora bakterileri benzer sonuçlar göstermiştir.

\section{Enzim Aktivitelerinin Belirlenmesi}

Proteaz, lipaz, kitinaz ve aljinat liazlar gibi çeşitli enzimlerin denizsel Streptomyces'ler tarafından üretildiği bildirilmiştir (Dharmaraj, 2010). Streptomyces ayrıca, L-asparagini L-aspartik aside ve amonyağa dönüştüren ve kemoterapötik bir ajan olarak kullanılan bir enzim olan iyi bir L asparaginaz kaynağı olarak da görev yapar (Fisher ve Wray, 2002). L-asparaginaz son yıllarda antikarsinojenik potansiyeli nedeniyle artan ilgi görmüştür. S. karnatakensis, S. venezualae, S. longsporusflavus ve $S$. albidoflavus gibi birçok karasal Streptomyces, saptanabilir miktarda L-asparaginaz üretme yeteneğine sahiptir (Narayana ve ark., 2008). $S$. aurantiacus gibi deniz Streptomyces'lerinden L-asparaginaz üretimi konusunda sinırlı sayıda rapor bulunmaktadır (Gupta ve ark., 2007).

Enzim aktivitesine göre asparaginaz (+) türlerin \%84,6'sı S.exfoliatus türü olduğu belirlenerek bu izolatların birbirlerine olan benzerliğide \%96,72 olarak belirlenmiştir. Asparaginaz (+) türlerden D0018 izolatı \%99,34 oranında S.purpureus olduğu belirlenmiştir. Selülaz (+) olan D0074 türümüzünde \%99,98 oranında S.exfoliatus olduğu belirlenmiştir. Amilaz ve Lipaz enzim aktivitesi için tüm izolatlarımız (-) sonuç göstermiştir. Proteaz (+) izolatlarımızın çoğunluğu Strerptomyces exfoliatus, bir izolatın da Streptomyces atroolivaceus olduğu belirlenmiştir.

Enzim aktivite çalışmaları IDENTAX programına göre toplam Streptomyces izolatlarının \%15'i asparaginaz, \%5'i proteaz, sadece D0074 suşu selülaz enzim aktivitesi gösterirken, hiçbir suşta amilaz ve lipaz enzimleri aktivite göstermemiştir.

\section{Nümerik Analiz Sonuçları ve Bilgisayar Yardımıyla Teşhis}

Seçilen 80 Streptomyces test suşu için yapılan 69 farklı testin sonuçları MVSP 3.2 (Multi-Variate Statistical Package) programında $S_{S M}$ katsayısına göre UPGMA (Unweighted Pair Group Method with Arithmetic Average Cluster ) analizleri yapılmıştır (Şekil 3). Dendogram \%85 benzerlik oranına göre toplam 9 küme oluştururken bu kümelerin 4'ü major, 5'i minör olur iken, 2 tane tekli üye oluşturmuştur. Oluşan kümeler IX. küme 39 izolat içerirken, diğer major gruplar 10'un üzerinde izolat içermiştir. IX. kümede yer alan D0001 ve D0080 nolu izolatların 4 nolu (Geyve -kuzey) lokasyondan olduğu ve \%99 'a yakın benzerlik gösterip IDENTAX teşhis programında da aynı tür olduğu tespit edilmiştir. Tekli üyelerden D0055, D0056 izolatları 4 nolu (Geyve -kuzey), D0059, D0060, D0064 izolatları 5 nolu (Geyve-güney) lokasyondan alınmıştır. Yoğun olarak test suşları \%95 üzerinde benzerlik göstermiştir. İzolatların tümünde oluşturduğu kümelerde bulunan üyelerin rakım ve alındığı lokasyon bakımından paralellik gösterdiği görülmüștür.

Williams ve arkadaşları (1983a), 394 tip Streptomyces bakterisini incelemiş ve 139 karaktere göre \% 77,5 benzerlik gösterenleri, 19 büyük ve 40 küçük küme grubuna ayırmıştır. Bu veriler ile olasılık tanımlama matriksi oluşturan Williams ve arkadaşları aynı yıl (Williams ve ark., 1983b) en önemli 41 karakteri seçmiș ve 19 Streptomyces kümesi ve belirleyici olarak 2 Strepioverticillium ve "Nocardia mediteiranea" ile olasllk tanımlama matriksini, MATIDEN 
bilgisayar programında kullanmıştırlar. Yine Öztürk (2000) yapmış olduğu çalışmada $\mathrm{S}_{\mathrm{SM}}$ analizi ile \% 82,5 benzerlik seviyesi gösteren yedi majör, 9 minör ve 10 tek üyeli küme belirlemiștir. Bizim çalışmamız da nümerik analiz için yapılan 69 test sonuçlarının tamamı MVSP 3.2 (Multi-Variate Statistical Package; Ek IV) programına 1/0 olarak girilerek analizleri yapılmıştır. UPGMA (Unweighted pair group method with arithmetic average) Cluster Analizi $\mathrm{S}_{\mathrm{SM}}$ (simple macthing coefficient) benzerlik dendogramları oluşturulmuştur. $\mathrm{Bu}$ dendogramda $\left(\mathrm{S}_{\mathrm{SM}}\right)$ sonuçlarına göre \% 85 benzerlik oranı esas alındığında test Streptomyces bakterileri 9 grup ve 2 tekli üyeye ayrılmıştır. $\mathrm{S}_{\mathrm{SM}}$ kofisiyenti ile elde edilen dendogramdaki kümeler en az bir ve en fazla 39 suş içermiştir.Ayrıca çalışmamızda test organizmaları $S_{S M}$ katsayısına göre oluşan kümeler renk gruplandırmasında oluşan kümelerle uygunluk göstermiştir. 4 major , 5 minör ve 2 tek üyeli küme oluşmuştur. Farklı lokasyonlardan izole edilen test suşları nümerik taksonomi dendogramında çoğunlukla homojen kümeler oluşmuştur. Bu noktada farklı habitatlarda yaşayan Streptomyces türlerinin farklılık gösterdiğini belirtebiliriz. Sonuçlarımız topraktan izole edilmiş suşların pigmentasyonuna göre oluşan kümeler aynı nümerik taksonlara ayrıldığını desteklemektedir (Williams ve Vickers, 1988). Her ne kadar nümerik analiz sonucu oluşan dendogram tekli üyeler barındırsa da izole edilen test suşları oluşan kümelerde tam olarak ayrışma göstermiştir. Yani aynı lokasyonden izole edilen suşlar çoğunlukla aynı kümelerde yer almıştır.

Williams ve ark., (1983b) ve Langham ve ark. (1999) tarafından Streptomyces major kümeler için belirledikleri teşhis matrikslerine göre yapılan teşhislerde 1. renk grubundan seçilen izolatlar S. exfoliatus, $S$. atroolivaceus, S. chromofuscus, S. purpureusoldukları belirlenmiştir. Renk gruplandırması aynı olan Streptomyces türleri nümerik analiz sonucu aynı grupta yer almıştır ve çalışmalarımızla uyumluluk göstermiştir.

Streptomyces suşlarının yapılan testlere göre bilgisayar yardımıyla teşhisleri için IDENTAX Bacterial Identifier1.2 programı kullanılarak tek benzerlik matriksi kullanılmıştır. Bu majör (Williams ve ark., 1983b) ve minör kümeler (Langhman ve ark., 1999) için belirlenen benzerlik matriksidir. Bu matriks ile teşhis edilen suşların mevcut benzerlik matriksleri içerisinde en fazla benzerlik gösterdikleri tür en yakın takson olarak kabul edilmiştir. Sonuçta toplam 80 Streptomyces suşundan 13 tanesi dışındaki toplam 67 izolatın programa göre kesin teşhisleri yapılmıştır. 13 adet izolatın mevcut taksonomik gruplarda yer alan türlerle \%85'in altında benzerlik göstermesinden dolayı teşhisin tamamlanamadığı belirlenmiștir.

Kullandığımız teşhis matriksi Williams ve ark., (1983b) tarafından topraktan izole edilen Streptomyces suşlarının \%81,3'ünü, Stanton (1984) sudan izole ettiği suşların \%43,8'ini, Goodfellow ve Haynes (1984) deniz suyundan izole ettikleri suşların \%70'ini ve Atalan (1995) ise \%80'ini doğru teşhis etmişlerdir. Yine Saddler (1988) farklı habitatlarda izole ettiği Streptomyces suşlarının \%70'ini teşhis etmiştir. Çalışmamızda ise test suşlarımızın \%83,75'i teşhis edilmiştir. Bu değer önceki teşhis oranları ile uygunluk göstermektedir. Bununla birlikte teşhis matriksi mevcut Streptomyces türlerin verilerini tam içermediği için eksik kalmaktadır.

Çizelge 1 .Toplanan toprak numunelerinin nem ve $\mathrm{pH}$ değerleri

\begin{tabular}{llll}
\hline Lokasyon & Alınan lokasyon & Nem (\%) & $\mathrm{pH}$ \\
\hline 1.lokasyon & Karaçam çıkışı & 4 & 6,13 \\
2.lokasyon & Doğançay (Aşağı mahalle) & 9 & 6,89 \\
3.lokasyon & Doğançay (Yukarı mahalle) & 9 & 6,79 \\
4.lokasyon & Geyve (Kuzey) & 8 & 7,16 \\
5.lokasyon & Geyve (Güney) & 8 & 6,69 \\
\hline
\end{tabular}

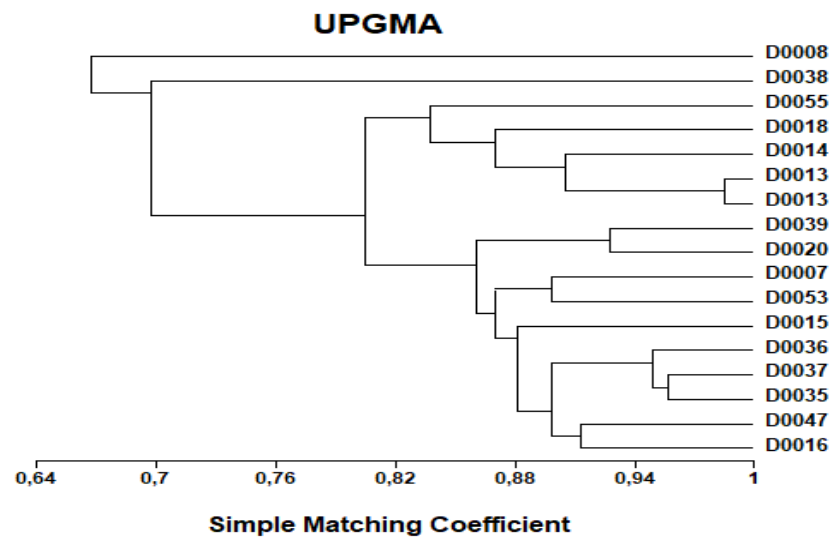

Şekil 3. Tüm Streptomyces test izolatlarından seçilen temsilcilere 69 farklı karakter bakımından uygulanan test sonuçlarının MVSP 3.2. (Multi Variate Statiscial Package) programı ( $\mathrm{S}_{\mathrm{SM}}$ : Simple Matching Coefficient) Basit Eşleştirme Katsayısı ile oluşturulan dendogramı. 


\section{Sonuç}

Streptomyces bakterileri endütriyel anlamda oldukça önemli bir cinstir. Dolayısıyla bu cinslerin teşhisi önem arz etmektedir. Yaptığımız çalışma ile Streptomyces bakterilerinin 69 farklı testle bilgisayar yardımı ile teşhisleri yapılmıştır. Enzim aktivite sonuçlarını göz önünde bulundurarak, özellikle asparaginaz enzimi için türlerimizin \%15'inin pozitif olması ile sonuçlarımızın oldukça anlamlı olduğu ve asparaginaz enziminin uygulamalı tıpta kullanımı düşünüldüğü zaman pozitif suşlarımızın bu enzimin biyoteknolojisinde oldukça faydalı olacağı kanaatindeyiz.

Sonuç olarak, endüstriyel enzimler olan amilaz, selülaz, L-asparaginaz, proteaz ve lipaz çeşitli mikroorganizmalardan elde edilebilirler. Günümüzde birçok endüstriyel kullanım alanı bulmuş olan bu enzimler yapılan çalışmaların ışığında kullanım alanlarının gelecekte daha da artacağı açıktır.

\section{Kaynaklar}

Atalan E, Manfio GP, Ward AC, Kroppenstedt RM, Goodfellow M. 2000. Biosystematic studied on novel Streptomycetes from soil. Antonie van Leeuwenhoek 77:337-353.

Atalan E. 1995. Identification of Streptomyces isolated from environmental soil samples using rapid enzyme data. Journal of Environmental Science and Health Part A 30(6):1133-1143.

Aygan A, Arikan B, Korkmaz H, Dinçer S, Çolak 0. 2008. Highly thermostable and alkaline $\alpha$-amylase from a halotolerant-alkaliphilic Bacillus sp. AB68. Braz. J. Microbiol. 39(3):547-53.

Demain AL, Solomon, NA. 1981. In Industrial Microbiology and the Advent of Genetic Engineering, pp. 3-14. Scientific American, Freeman \&Comp., San Francisco.

Dharmaraj S. 2010. Marine Streptomyces as a novel source of bioactive substances. World Journal of Microbiology and Biotechnology 26:2123-2139.

Ertaş M, Özdemir K, Atalan E. 2013. Isolation and characterization of Micromonospora bacteria from various soil samples obtained around Lake Van. African Journal of Biotechnology 12(21):3283-3287.

Fisher SH, Wray Jr LV. 2002. Bacillus subtilis 168 contains two differentially regulated genes encoding L-asparaginase. Journal of Bacteriology 184:2148-2154

Goodfellow M, Haynes JA. 1984. Actinomycetes in marine sediments. In Biological biochemical and biomedical aspect of Actinomycetes. Academic Pres, Newyork, 452-472.

Gulati R, Westhphal JD, Shortell SM. 1997. Customization or Conformity? An Institutional and Network Perspective on the Content and Consequences of TQM Adoption. Administrative Science Quarterly 42:366-394.

Gupta N, Mishra S, Basak UC. 2007. Occurrence of Streptomyces aurantiacus in mangroves of Bhitarkanika. Malaysian Journal of Microbiology 3:7-14.

Hakamada Y, Koike K, Yoshimatsu T, Mori H, Kobayashi T, Ito S. 1997. Thermostable alkaline cellulase from an alkaliphilic isolate, Bacillus sp. KSM-S237. Extremophiles, 1:151-156.

Hamdi YA, Ahmed D, Al-Tai, A.M. 1980. Genera and species of actinomycetes isolated from Iraqi soils. Egyptian Journal of Microbiology 15:7-22.

Hayakawa M, Yoshida Y, Imura Y. 2004. Selective isolation of bioaktive soil Actinomycetes belonging to the Streptomyces violaceusniger phenotyphic cluster. Journal of Applied Microbiology 96:973-981.

Hussein AM, Rajab AM, Elgammal AA, Mansour FA, Sami E, Helmy M, Sheheta NE. 1980. Taxonomy of gray pigmented Streptomyces spp. isolated from Egyptian soil. Egyptian Journal of Botany 23:9-16.

Jones KL. 1949. Fresh isolates of actinomycetes in which the presence of sporogenous aerial mycelia is a fluctuating characteristic. Journal of Bacteriology 57:141-145.

Karnetova J, Mateju J, Rezarka T, Prochazka P, Nohynek M, Rokes J. 1984. Estimation of lipsae activity by the diffusion plate method. Folia Microbiologica 29:346-347.

Langham CD, Williams ST, Sneath PHA, Mortimer AM. 1999. New probability matrices for identification of Streptomyces. Journal of General Microbiology 135:121- 133.

Narayana KJP, Kumar KG, Vijayalakshmi M. 2008. L-asparaginase production by Streptomyces albidoflavus. Indian Journal of Microbiology 48:331-336.

Orhan E, 2013. Tuzcul Habitatlardan Alınan Toprak Numunelerinden Halofilik Streptomyces Türlerinin İzolasyonu, Karakterizasyonu ve Teşhisi. Yüksek Lisans Tezi. Van Yüzüncü Yıl Üniversitesi Fen Bilimleri Enstitüsü, Van.

Özdemir K. 2008. Lens orientalis (Boiss.) Hand \& Mazz. ve Cicer anatolicum Alef. rizosferinden Streptomyces türlerinin izolasyonu, teşhisi ve karakterizasyonu. Doktora tezi. Yüzüncü Yıl Üniversitesi, Fen Bilimleri Enstitüsü, Van.

Öztürk E, 2000. Termofilik Streptomyces'lerin İzolasyonu ve Nümerik Taksonomisi. Y.L.Tezi. Ondokuz Mayıs Üniversitesi, Fen-Edebiyat Fakültesi, Biyoloji Bölümü, Samsun, Türkiye.

Saadoun I, Mohammadi MJ, Al-Momani F, Meqdam M. 1998 Diversity of soil streptomycetes in northern Jordan. Actinomycetes 9:53-58.

Saddler GS. 1988. Selective isolation and rapid identification of streptomycetes. Ph.D. Thesis, Department of Microbiology, University of Newcastle upon Tyne (UK). 
Seçkin H, 2018. Van Gölüne Dökülen Akarsulardan Streptomyces Türlerinin İzolasyonu Teşhisi ve Moleküler Tanısı. Doktora Tezi. Van Yüzüncü Yıl Üniversitesi Fen Bilimleri Enstitüsü, Van.

Semêdo L, Gomes RC, Linhares AA, Duarte GF, Nascimento RP, Rosado AS, Margis-Pinheiro M, Margis R, Silva K, Alviano CS, Manfio GP, Soares R, Linhares LF, Coelho R. 2004. Streptomyces drozdowiczii sp. nov., a novel cellulolytic streptomycete from soil in Brazil. International Journal of Systematic and Evolutionary Microbiology 54:13231328.

Shirling EB, Gottlieb D. 1966. Methods for characterization of Streptomyces species. International Journal of Systematic Bacteriology 16:313-340.

Stanton LJ. 1984. Actinomycetes Associated with Freshwater Habitats. PhD thesis, University of Newcastle upon Tyne.

Vickers JC, Williams ST, Ross GW. 1984. A taxonomic approach to selective isolation of Streptomyces. In Biological, Biochemical and Biomedical Aspects of actinomycetes, pp. 553-561. Edited by L. Ortiz-Ortiz, L. F. Bojalil and V. Yakoleff. Academic Press: Orlando.

Williams ST, Goodfellow M, Alderson G, Wellington EMH, Sneath PHA, Sackin MJ. 1983a. Numerical classification of Streptomyces and related genera. Journal of General Microbiology 129:1743-1813.

Williams ST, Goodfellow M, Wellington EMH, Vickers JC, Alderson G, Sneath PHA, Sackin MJ, Mortimer AM. 1983b. A probability matrix for identification of some streptomycetes. Journal of General Microbiology 129:1815- 1830.

Williams ST, Vickers JC. 1988. Detection of actinomycetes in the natural environment-problems and perspectives. In Biology of Actinomycetes 88, Edited by Y. Okami, T. Beppu ve H. Ogawara, Japan Scientific Societies Pres, Tokyo, 265-270.

Wiseman A. 1987. Handbook of Enzymes Biotechnology. Second Edition. C 3. The Application of Enzymes in Industry p. 274-373.

Yin C, Kikuchi K, Hochgreb T, Poss KD, Stainier DY. 2010. Handz Regulates Extracellular Matrix Remodeling Essential for Gut-Looping Morphogenesis in Zebrafish. Developmental Cell 18(6): 973-984 